\title{
Reproduction of Human Capital as a Strategic Priority for Sustainable Development of Regions
}

\author{
Wzrost kapitału ludzkiego jako strategiczny \\ priorytet zrównoważonego rozwoju regionów
}

Olena Krasnonosova*, Daria Mykhailenko*, Ihor Yaroshenko***

\author{
Macroeconomic Analysis and Forecasting Sector of the \\ Macroeconomic Policy and Regional Development Department, \\ Research Center for Industrial Development Problems of the National Academy of Sciences \\ of Ukraine, Kharkiv, la Inzhenernii lane, 61166, Ukraine \\ *E-mail: krasnonosova@gmail.com, ORCID:0000-0002-0863-3705 \\ **E-mail: mikhailenko.dg@gmail.com,ORCID: 0000-0002-8420-6510 \\ ***E-mail: iyaroshenko@i.ua, ORCID:0000-0001-7107-5550
}

\begin{abstract}
The main wealth of the country, its main strategic resource that can ensure political, economic, environmental, and spiritual growth, is human capital. Its intellectual, entrepreneurial, and productive potential, the ability to create and accumulate knowledge, implement it in the production of goods and services, develop unique technologies, invent new types of energy, materials, information, etc., is the engine of scientific and technological progress and innovative restructuring of the economy. Investment in human capital, in intelligence, in the health of the nation, in education and science, and in creating conditions for the normal functioning of everyone is a prerequisite not only for improving the quality of life of the people, but also for achieving the Millennium Goals and Sustainable Development Goals, advancing the country's development, and its social and political stability.

The research is aimed at developing theoretical, methodological, and practical provisions for the formation of strategic priorities for sustainable development of territories based on the reproduction of human capital. The theoretical basis was the available scientific works, certain provisions of normative legal acts, international framework documents, in particular from United Nations: Agenda 21 and the report Our Common Future, as well as local studies.

The generalization of various scientific points of view regarding the category of human capital allowed us to establish that it is an integral part of its carrier, and therefore, it is proposed to understand as such a set of personal qualities of a person formed, developed, accumulated and preserved as a result of investments in productive abilities, personal qualities and motivational behavior of an individual, as well as the ability to develop and accumulate the necessary qualities that are in his property, which he uses in economic activities and which provides him with a corresponding income.

The article substantiates the value of the category human capital for sustainable development. The territorial features of the reproduction of human capital are determined, based on which it is proposed to consider the region as space. It is proved that the reproduction of human capital occurs in the relationship and interdependence with the general periods of the life cycle of the generation, which served to distinguish the four phases of the reproduction of human capital. The architectonics of determining the strategic priorities of sustainable development of territories based on the reproduction of human capital, which is aimed at solving theoretical, methodological, and applied problems, is proposed.
\end{abstract}

Key words: ecology, economy, society, sustainable development, human capital, reproduction, strategic priorities 


\section{Streszczenie}

Głównym bogactwem kraju, jego głównym zasobem strategicznym, który może zapewnić rozwój polityczny, gospodarczy, środowiskowy i duchowy, jest kapitał ludzki. Jego potencjał intelektualny, przedsiębiorczy i produkcyjny, zdolność do tworzenia i gromadzenia wiedzy, wdrażania jej w produkcji towarów i usług, rozwijania unikalnych technologii, wynajdywania nowych rodzajów energii, materiałów, informacji itp. jest motorem postępu naukowo-technicznego i innowacyjności restrukturyzacji gospodarki. Inwestowanie w kapitał ludzki, w inteligencję, w zdrowie narodu, w edukację i naukę oraz w tworzenie warunków do normalnego funkcjonowania wszystkich jest warunkiem nie tylko poprawy jakości życia ludzi, ale także osiągnięcia Celów Milenijnych i Celów zrównoważonego rozwoju, w celu rozwoju kraju oraz wzrostu jego stabilności społecznej i politycznej.

Badania mają na celu wypracowanie teoretycznych, metodologicznych i praktycznych zapisów dla kształtowania strategicznych priorytetów zrównoważonego rozwoju terytoriów w oparciu o wzrost kapitału ludzkiego. Podstawą teoretyczną były dostępne opracowania naukowe, niektóre zapisy normatywnych aktów prawnych, międzynarodowe dokumenty ramowe, w szczególności ONZ: Agenda 21 i raport Nasza Wspólna Przyszłość, a także opracowania lokalne.

Uogólnienie różnych naukowych punktów widzenia w odniesieniu do kategorii kapitału ludzkiego pozwoliło ustalić, że jest on integralną częścią jego nosiciela, a zatem proponuje się rozumieć jako taki zespół cech osobowych ukształtowanej osoby, rozwijane, gromadzone i utrwalane w wyniku inwestycji w zdolności produkcyjne, cechy osobiste i zachowania motywacyjne jednostki, a także zdolność do rozwijania i gromadzenia niezbędnych cech znajdujących się w jej własności, którą wykorzystuje w działalności gospodarczej oraz co zapewnia mu odpowiedni dochód.

Artykuł uzasadnia wartość kategorii kapitału ludzkiego dla zrównoważonego rozwoju. Określane są terytorialne cechy reprodukcji kapitału ludzkiego, na podstawie których proponuje się traktować region jako przestrzeń. Udowodniono, że reprodukcja kapitału ludzkiego zachodzi w relacji i współzależności z ogólnymi okresami cyklu życia pokolenia, co posłużyło do wyodrębnienia czterech faz reprodukcji kapitału ludzkiego. Zaproponowano architektonikę wyznaczania strategicznych priorytetów zrównoważonego rozwoju terytoriów w oparciu o reprodukcję kapitału ludzkiego, która ma na celu rozwiązywanie problemów teoretycznych, metodologicznych i aplikacyjnych.

Słowa kluczowe: ekologia, ekonomia, społeczeństwo, zrównoważony rozwój, kapitał ludzki, reprodukcja, cele priorytetowe

\section{Introduction}

Modern processes of development of society, and, consequently, the main components of its life activity, to a significant extent, depend on the implementation of the concepts of sustainable development. The development and dissemination of innovative (digital) technologies become an inevitable and necessary process, the result of which is manifested in the creation of new, progressive means of production and technologies. This, in turn, leads to the intellectualization of all spheres of human economic activity. As the world experience shows, the innovative development of the economic and social territorial space, first of all, depends on the quality of the available human capital, which becomes the main component of the knowledge economy. Modern trends in the creation and accumulation of new knowledge in all areas of science and technology provide not only a high educational, qualification, and cultural level of the individual, but also radically change his position in social production and social life, the basic model of which is the reproduction of human capital. Thus, the issues of the reproduction of human capital, as one of the main strategic priorities of sustainable development of territories, are relevant and require the development of a scientifically based mechanism.

\section{Methodology}

The theoretical and methodological basis of the article proposed for consideration was made up of early studies of scientists from different countries, generations, and areas of scientific interest since the theory and methodology of sustainable development are multifaceted and endless. Thus, the works of regional scientists and demographers were used in the formation of conceptual provisions regarding human capital and its development in the future.

In particular, the authors' opinions about the current priorities of socio-economic development are based on the research of N. G. Belopolsky under the scientific editorship of Academician of the National Academy of Sciences of Ukraine A. I. Amoshi, who proposed a new concept for the development of the world environ. (Belopolsky, 2020).

Scientific developments of the staff of the National Academy of Sciences of Ukraine N. Briukhovetska, L. Ivanenko, they determined the allocation of the values of the category human capital for sustainable development (Briukhovetska, Ivanenko, 2020). The work of the personnel of the Research Center for Industrial Problems of Development of the National Academy of Sciences of Ukraine allowed us to identify the main elements of the territorial space in the context of sustainable development. 
The dependence of the reproduction of human capital with the general periods of the life cycle of the generation was established thanks to the scientific foundation of the fundamentalists Solow (Solow 1974), J. Hartwick (Hartwick, 1977), T. Page, I. Y. Blam, T. Titenberg, R. K. Turner, D. Pierce, G. Atkinson, N. Georgescu-Roegen, etc. whose works are the basis of the modern resource approach to the consideration of the problems of the development of socio-economic systems and contemporaries I. Bakhov, E. Boychenko, N. Martynovych, N. Streltsova, 2014 , the articles of which raise the issues of the formation of the socio-cultural, educational levels of the individual in modern society. In particular, the research of N. Streltsova allowed us to identify the main phases of the reproduction of human capital, and the works of I. Bakhov (Bakhov, 2020), E. Boychenko (Boychenko, 2015), N. Martynovych (Martinovich, 2019) to establish the relationship between the economic, environmental and social components, the phases of the reproduction of human capital and the goals of sustainable development.

The practical application of the proposed architectonics allowed us to display the grouping method, which involves the distribution of many units of the studied population: (the EU countries and Ukraine) into groups by the priority feature for each group.

The main conclusions regarding strategic priorities and prospects for sustainable development were made thanks to the fundamental research of $P$. Senge (Senge, 2008), A. Pawlowski (Pawlowski, 2015), A. Skowronski (Skowronski, 2003), as well as international framework documents, in particular: Agenda 21 (Environment \& Society Portal, 1987) and the report Our Common Future (WCED, 1987) prepared by the International Commission on Environment and Development of the United Nations.

The purpose of this study is to develop theoretical, methodological, and practical terms for the formation of strategic priorities for sustainable development of territories based on the reproduction of human capital.

\section{Findings and Discussion}

The results of the conducted research give grounds to assert that the essence of human capital is expressed in the following.

Firstly, it is a set of personal qualities of a person, which it is advisable to include his physiological characteristics: gender, age, level of health; intellectual characteristics: level of education, knowledge, professional skills and work experience, ability and motivation to receive additional education, professional skills, related specialties, etc.; cultural: the general level of personal culture, professional culture and ethics, and so on. Secondly, the formation, development, and preservation of the aggregate personal qualities of a person occur as a result of investments and the accumulation of a certain stock of them. Thirdly, the use of human capital by its owner takes place to obtain a corresponding income (salary), depending on its quality. Fourthly, the development and preservation of human capital determines the growth of labor productivity, encourages further investment in human capital, and contributes to the growth of personal income (wages).

When defining the essence of the concept of human capital, it is important to understand that it is an integral part of its carrier. This feature has important theoretical and practical implications. Thus, for ordinary capital, there are two types of prices in the market: the assets and the flows of services that it provides. Human capital can only be rented (by hiring an employee), the person himself cannot be the subject of purchase and sale. Thus, it can be argued that there is only one rental price of human capital wages. In all other respects, human capital is similar to physical capital, which is a boon of long-term use, but with limited service life.

Based on the above, human capital is understood as a set of personal qualities of a person formed, developed, accumulated, and preserved as a result of investments in productive abilities, personal qualities, and motivational behavior of an individual, as well as the ability to develop and accumulate the necessary qualities that are in his property, which he uses in economic activities and which provides him with an appropriate income.

The value of the category human capital for sustainable development is explained by the following reasons:

$\checkmark \quad$ in the concept of human capital, a person is considered in the unity of economic, social, and environmental aspects;

$\checkmark$ looking at human health, knowledge, and abilities as income-generating capital, scientifically justify and proves the necessity and economic feasibility of investing in a person in various areas and at all levels;

$\checkmark \quad$ the concept of human capital characterizes a free person who is an equal agent in the labor market;

$\checkmark$ the concept of human capital is the economic basis for the general humanitarian concept of sustainable development (Briukhovetska, Ivanenko, 2020).

The formation, use, and development of human capital in the context of the knowledge economy should be considered as the most important factor in the implementation of the concept of sustainable development, on the one hand, and the other, as a factor in the development of human capital itself, as a structural element of the economy.

Considering the territorial features of the reproduction of human capital, it should be noted that its formation and use in each territory takes place in the conditions of national, ethnic, religious, cultural and other traditions (Bakhov, 2020), (E. Boychenko, 2015), (N. Martinovich, 2019). The main elements 
of the territorial space include: 1$)$ territorial integrity, which in turn is considered through conglomeration (accommodates the mechanical connection of heterogeneous objects and objects) and potential (the possibilities of using available resources), and 2) the development of the territory, which involves the reproduction of potential, saturation with economic objects and connections, human resources, involvement in social production.

It should be noted that the territorial space determines the parameters of the geographical contour of the region, the structure of population settlement (territorial differentiation), the organization of the economy, infrastructure, and so on. Thus, the reproduction of human capital takes place in a certain territory, due to the natural and climatic habitat of its inhabitants.

At the same time, the territory is understood as a set of spatially coinciding parts of economic, social, natural resource, recreational, demographic, and other potentials. Territorial features of the reproduction of human capital with their specific conditions (geographical, natural and climatic, historical, economic, social, environmental, demographic, cultural, educational, etc.) affect the formation of the economic complex of the territory, which is a combination of industry, functional and territorial structure. It is the specific features of the economic complex that determine the structure of socio-economic relations of the reproduction of human capital.

The reproduction of human capital occurs in interrelation and interdependence with the general periods of the life cycle of a generation. It should be noted that a generation is a collection of people born in the same period (year). When considering a generation, it is important that all persons belonging to the generation in question experience physiological development, personality formation, and socialization simultaneously. It is advisable to consider the reproduction of human capital from the point of view of the following stages: natural reproduction of the population at a certain time, in a certain territory; accumulation of natural abilities, including the level of physical and mental health, intelligence, culture, morality, motivation, etc.; acquisition of the necessary educational, professional and qualification skills, knowledge and skills (Streltsova, 2014)

Based on all that has been said by the authors, a rendering of the relationship between the reproduction of human capital and the strategic priorities of sustainable development of territories is proposed in (Fig. 1).

The figure shows that the $\mathrm{X}, \mathrm{Y}$, and $\mathrm{Z}$ axes represent the components of sustainable development, in particular, the $\mathrm{X}$-axis is the economic component of sustainable development, the $\mathrm{Y}$-axis is the social component of sustainable development, and the Z-axis is the environmental component of sustainable development. All three axes are placed in space, and allow you to display the territory (city, region, country) as space.

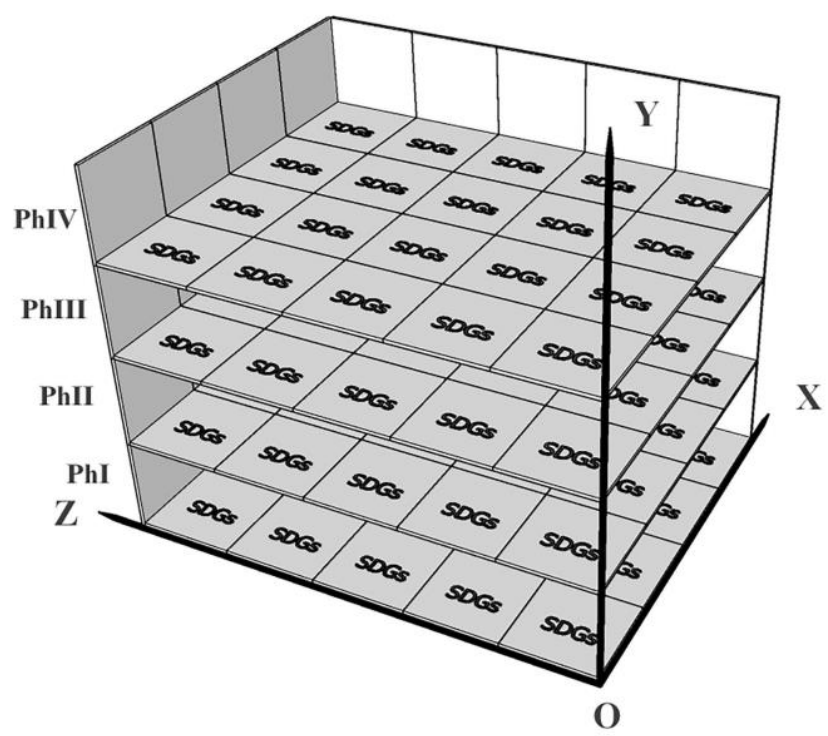

Figure 1. Architectonics of strategic priorities for sustainable development of territories, Author's development

On each axis of the components of sustainable development (economic, social, environmental), the phases of human capital reproduction are represented, which are indicated in the figure as PhI, PhII, PhIII, PhIV. These phases allow us to outline strategic priorities for the development of the territory based on the formation of priorities for the development of human capital since after a certain period (life cycle), priorities change. This is evidenced by the fact that before 2015 there were eight United Nations Millennium Development Goals, and after 2015 there were 17 Sustainable Development Goals (Official portal of the United Nations, 1987). It is possible that in the future, both the number and content of these goals will change, which in turn will affect the content of the strategic priorities and objectives of sustainable development of the regions of Ukraine. Relying on the current Millennium Goals, we concluded that the strategic priorities for the sustainable development of the regions of Ukraine should be aimed at achieving the following main objectives:

1. At the PhI formation phase:

$\checkmark \quad$ an increase in the birth rate, which will neutralize negative changes in the structure of the population, will stop the processes of depopulation and create conditions for its rejuvenation;

$\checkmark$ reducing the outflow of the working-age population outside the territory, by improving the quality of life of the population, which will preserve the most competitive, educated, professional part of the population;

$\checkmark$ increasing the coverage of children in extracurricular education is a prerequisite for intellectual, creative, and cultural development; 
$\checkmark \quad$ improving the quality of general and vocational education by increasing its funding and adapting it to the needs of the labor market;

$\checkmark$ reform of the vocational education system based on the principle of justifying the need for specialists in the relevant professions and the level of education, which should be based on the prospective needs of the labor market.

2. In the PhII usage phase:

$\checkmark$ creation of new jobs, which is the key to improving the quality of life of the population and the effective use of human capital;

$\checkmark$ creating conditions for professional mobility, which will allow to diversify the flow of specialists between sectors of the economy and provide employment for the population;

$\checkmark \quad$ the creation of activities that will promote and motivate the self-employment of the population, solve the problem of jobs, increase the possibility of obtaining a stable income and economic development;

$\checkmark \quad$ improving working conditions and jobs.

3 . In the PhIII accumulation phase:

$\checkmark$ creating conditions for lifelong learning, which is the basis for improving labor productivity;

$\checkmark \quad$ creating conditions, promoting motivation to invest in the professional development of human capital at the personal micro-and macro-level.

4. In the PhIV conservation phase:

$\checkmark$ creating conditions, promoting and promoting the motivation of the population to support a healthy lifestyle, physical activity, and disease prevention;

$\checkmark$ development of measures to reduce workplace injuries and occupational diseases;

$\checkmark$ development of social insurance (life, medical, and pension provision).

Before going directly to the sustainable development goals, their role and place in architectonics, as well as their relationship with other elements of the spatial model of territorial development (Figure 1), we will focus in more detail on the category of sustainable development itself. In the course of the study, it was found that the concept of sustainable development was first mentioned in 1987 in the report Our Common Future, which was prepared by the UN International Commission on Environment and Development under the leadership of Brundtland. The document notes that sustainable development is development that meets the needs of the present without compromising the ability of future generations to meet their own needs (WCED, 1987).

At the same time, the analysis of the scientific points of view of various authors, regarding the interpretation of the concept of sustainable development, gives grounds to assert that the majority of scientists, the classical definition of sustainable development is not the interpretation of the International Commission on Environment and Development of the United Nations, but what is presented in the UN
Framework Document Agenda 21: sustainable development is a model of the movement of humanity forward, in which the needs of the current generation of people are met without depriving future generations of this opportunity (Environment \& Society Portal).

In the Sustainable Development Strategy Ukraine2020, the interpretation of the category is as follows: this is the process of state development based on the coordination and harmonization of social, economic and environmental components to meet the needs of modern and future generations (Official portal of the Verkhovna Rada of Ukraine, 2015).

Thus, based on the presented definitions, as well as taking into account the phases of human capital reproduction, it can be stated that the complex nature of these elements does not allow us to consider them separately from the sustainable development goals, as well as the fact that they are strategic priorities for the sustainable development of the territory. This thesis is reflected in the agenda for the twenty-first century, where it is stated: that ensuring the reproduction of human capital (territorial community) is primarily the responsibility of the national government and requires the development of an appropriate national program and policy.

All of the above explains the presence in the architectonics of the reproduction of human capital of the presence of the Sustainable Development Goals, which in (Fig. 1) are designated as:

$\checkmark$ SDGs1 - Overcoming poverty in all its forms around the world,

$\checkmark \quad$ SDGs2-Stopping hunger, achieving food security, improving nutrition, and promoting sustainable agriculture,

$\checkmark \quad$ SDGs3 - Ensuring a healthy lifestyle and promoting the well-being of people of all ages, ...

$\checkmark$ SDGs17-Reinvigorating and strengthening the global partnership for sustainable development It is important to note that the positions of these goals may change depending on the characteristics of the regions, as well as the stages of the generation life cycle. The same applies to the density of connections, which can then weaken, then strengthen. To display the practical use of the proposed scientific and methodological tools, we will group the EU countries and Ukraine by individual indicators, namely: the level of population growth (decline), \% (Pg/d); Life expectancy at birth, female (years) (LEBf); Life expectancy at birth, male (years) $(\mathrm{LEBm})$; Labor force participation rate, female (\% of female population ages 15-64) (LFPRf); Labor force participation rate, male ( $\%$ of male population ages 15-64) (LFPRm); Unemployment rate, \% to the economically active population (UReap); Average monthly salary (AMS); Gross Domestic Product Per Capital (GDPpc). This list of indicators allows you to group countries according to the priorities of sustainable development. 


\begin{tabular}{|c|c|c|c|c|c|c|c|}
\hline $\mathrm{Pg} / \mathrm{d}$ & LEBf & LEBm & LFPRf & LFPRm & UReap & AMS & GDPpc \\
\hline $\mathrm{Pg} / \mathrm{d} 1$ & LEBf 1 & LEBm 1 & LFPRf 1 & LFPRm 1 & UReap 1 & AMS 1 & GDPpc 1 \\
\hline$-1,4-(-0,68)$ & $76,73-78,38$ & $66,7-69,19$ & $56,2-60,47$ & $71,3-73,55$ & $19,3-16,4$ & $267,1-1252,4$ & $17,1-29,34$ \\
\hline $\begin{array}{l}\text { Lithuania (- } \\
1.4) \\
\text { Latvia }(-0.9)\end{array}$ & Ukraine (76.73) & Ukraine $(66,7)$ & $\begin{array}{l}\text { Italy (56.2) } \\
\text { Poland (59.3) } \\
\text { Romania (58.8) } \\
\text { Greece }(59.6)\end{array}$ & $\begin{array}{l}\text { Croatia }(71.3) \\
\text { Poland }(72.0) \\
\text { Belgium }(72.1) \\
\text { Luxembourg }(72.9) \\
\text { Ukraine }(73.4)\end{array}$ & Greece (19.3) & $\begin{array}{l}\text { Ukraine (267.1) } \\
\text { Romania (819.4) } \\
\text { Lithuania (948.3) } \\
\text { Hungary (1045.2) } \\
\text { Latvia (1046.1) } \\
\text { Poland (1122.5) } \\
\text { Croatia (1219.2) } \\
\text { Slovakia (1242.7) }\end{array}$ & $\begin{array}{l}\text { Ukraine (17.1) } \\
\text { Croatia (21.4) } \\
\text { Bulgaria (21.5) } \\
\text { Greece (25.1) } \\
\text { Romania (26.3) } \\
\text { Hungary (26.4) } \\
\text { Poland (26.6) } \\
\text { Portugal (27.3) } \\
\text { Slovakia (27.6) } \\
\text { Latvia (28.0) }\end{array}$ \\
\hline $\mathrm{Pg} / \mathrm{d} 2$ & LEBf 2 & LEBm 2 & LFPRf 2 & LFPRm 2 & UReap 2 & AMS 2 & GDPpc 2 \\
\hline$-0,68-0,04$ & $78,38-80,03$ & $69,19-71,68$ & $60,47-64,74$ & $73,55-75,8$ & $16,4-13,5$ & $1252,4-2237,7$ & $29,34-41,58$ \\
\hline $\begin{array}{l}\text { Romania }(-0.6) \\
\text { Bulgaria }(-0.7) \\
\text { Romania }(-0.6) \\
\text { Ukraine }(-0.4) \\
\text { Italy }(-0.2) \\
\text { Greece }(-0.2) \\
\text { Italy }(-0.2) \\
\text { Portugal }(-0.2) \\
\text { Croatia }(-1.0) \\
\text { Poland }(0,0) \\
\text { Estonia }(0,0)\end{array}$ & $\begin{array}{l}\text { Bulgaria (78.6) } \\
\text { Romania (79.2) } \\
\text { Hungary (79.6) } \\
\text { Latvia (79.7) } \\
\text { Slovakia (80.8) }\end{array}$ & $\begin{array}{l}\text { Latvia (70.1) } \\
\text { Lithuania (70.9) } \\
\text { Bulgaria (71.5) }\end{array}$ & $\begin{array}{l}\text { Ukraine (62.1) } \\
\text { Croatia (62.3) } \\
\text { Malta (63.6) } \\
\text { Belgium (64.0) } \\
\text { Hungary (64.1) } \\
\text { Luxembourg } \\
(66.5)\end{array}$ & $\begin{array}{l}\text { France }(74.0) \\
\text { Italy }(74.8) \\
\text { Bulgaria }(75.7) \\
\text { Cyprus }(76.1)\end{array}$ & Spain (15.3) & $\begin{array}{l}\text { Czech Republic } \\
\text { (1285.6) } \\
\text { Estonia (1379.4) } \\
\text { Portugal (1604.3) } \\
\text { Greece (1632.1) } \\
\text { Cyprus (2137.6) } \\
\text { Slovenia (2230.9) }\end{array}$ & $\begin{array}{l}\text { Estonia (30.0) } \\
\text { Czech Republic } \\
(30.6) \\
\text { Lithuania (30.6) } \\
\text { Italy (31.3) } \\
\text { Spain (32.3) } \\
\text { Cyprus (32.9) } \\
\text { Slovenia (33.1) } \\
\text { France (35.8) } \\
\text { Finland (37.7) } \\
\text { Malta (37.8) } \\
\text { Belgium (39.9) } \\
\text { Germany (41.1) }\end{array}$ \\
\hline $\mathrm{Pg} / \mathrm{d} 3$ & LEBf 3 & LEBm 3 & LFPRf 3 & LFPRm 3 & UReap 3 & AMS 3 & GDPpc 3 \\
\hline $0,04-0,76$ & $80,03-81,68$ & $71,68-74,17$ & $64,74-69,01$ & $75,8-78,05$ & $13,5-10,6$ & $2237,7-3223,0$ & $41,58-53,82$ \\
\hline $\begin{array}{l}\text { Slovakia }(0,1) \\
\text { Slovenia }(0,1) \\
\text { Czech } \\
\text { Republic }(0.2) \\
\text { Spain }(0.2) \\
\text { Finland }(0.2) \\
\text { France }(0.3) \\
\text { Belgium }(0.4) \\
\text { Germany }(0.4) \\
\text { Austria }(0.6) \\
\text { Netherlands } \\
(0.6) \\
\text { Denmark }(0.7)\end{array}$ & $\begin{array}{l}\text { Lithuania (80.7) } \\
\text { Croatia (81.5) }\end{array}$ & $\begin{array}{l}\text { Romania (71.7) } \\
\text { Hungary }(72.7) \\
\text { Poland }(73.7) \\
\text { Slovakia (73.9) } \\
\text { Estonia (74.0) }\end{array}$ & $\begin{array}{l}\text { Slovakia (66.2) } \\
\text { Bulgaria (67.1) } \\
\text { Ireland (67.1) } \\
\text { France (67.4) } \\
\text { Spain (68.5) } \\
\text { Cyprus (68.5) }\end{array}$ & $\begin{array}{l}\text { Greece }(76.8) \\
\text { Romania }(77.3 \\
\text { Hungary }(77.3) \\
\text { Slovenia }(77.8) \\
\text { Portugal }(78.0)\end{array}$ & Italy (10.6) & $\begin{array}{l}\text { Spain }(2642.0) \\
\text { Italy }(2750,2)\end{array}$ & $\begin{array}{l}\text { Denmark (41.9) } \\
\text { Austria (43.0) } \\
\text { Sweden (44.1) } \\
\text { Netherlands (46.3) }\end{array}$ \\
\hline $\mathrm{Pg} / \mathrm{d} 4$ & LEBf 4 & LEBm 4 & LFPRf 4 & LFPRm 4 & UReap 4 & AMS 4 & GDPpc 4 \\
\hline $0,76-1,48$ & $81,68-83,33$ & $74,17-76,66$ & $69,01-73,28$ & $78,05-80,03$ & $10,6-7,7$ & $3223,0-4208,3$ & $53,82-66,06$ \\
\hline $\begin{array}{l}\text { Cyprus (0.9) } \\
\text { Ireland (1.1) } \\
\text { Sweden (1.4) }\end{array}$ & $\begin{array}{l}\text { Poland (81.7) } \\
\text { Czech Republic } \\
(82.0) \\
\text { Estonia (82.7) } \\
\text { Denmark (82.9) } \\
\text { Germany (83.3) }\end{array}$ & $\begin{array}{l}\text { Czech Republic } \\
(76.2) \\
\text { Croatia (74.9) }\end{array}$ & $\begin{array}{l}\text { Czech Republic } \\
(69.6) \\
\text { Austria (71.3), } \\
\text { Slovenia (71.9), } \\
\text { Portugal (72.1) }\end{array}$ & $\begin{array}{l}\text { Spain (78.3) } \\
\text { Ireland (78.7) } \\
\text { Lithuania }(78.8) \\
\text { Finland }(78.8) \\
\text { Latvia }(78.9) \\
\text { Slovakia }(79.0) \\
\text { Austria }(79.6)\end{array}$ & $\begin{array}{l}\text { France }(9.1) \\
\text { Ukraine }(8.8) \\
\text { Croatia }(8.4) \\
\text { Cyprus }(8,4) \\
\text { Latvia }(7,4) \\
\text { Finland }(7,4)\end{array}$ & $\begin{array}{l}\text { France }(3541.8) \\
\text { Germany }(3713.6) \\
\text { Finland }(3906.1) \\
\text { Sweden }(3990,4) \\
\text { Austria }(4034,2) \\
\text { Belgium }(4127,2)\end{array}$ & Ireland (57.3) \\
\hline $\mathrm{Pg} / \mathrm{d} 5$ & LEBf 5 & LEBm 5 & LFPRf 5 & LFPRm 5 & UReap 5 & AMS 5 & GDPpc 5 \\
\hline $1,48-2,20$ & $83,33-84,98$ & $76,66-79,15$ & $73,28-77,55$ & $80,03-82,28$ & $7,7-4,8$ & $4208,3-5193,6$ & $66,06-78,3$ \\
\hline Hungary (1.5) & $\begin{array}{l}\text { Netherlands (83.4) } \\
\text { Belgium (83.9) } \\
\text { Ireland (84.1) } \\
\text { Austria (84.1) } \\
\text { Sweden (84.3) } \\
\text { Slovenia (84.4) } \\
\text { Greece (84.4) } \\
\text { Portugal (84.5) } \\
\text { Finland (84.5) } \\
\text { Luxembourg(84.6) } \\
\text { Malta (84.6) } \\
\text { Cyprus (84.8) }\end{array}$ & $\begin{array}{l}\text { Portugal (78.3) } \\
\text { Slovenia (78.5) } \\
\text { Germany (78.6) } \\
\text { Denmark (79.1) } \\
\text { Greece (79.3) }\end{array}$ & $\begin{array}{l}\text { Germany }(74,0) \\
\text { Latvia }(74,4) \\
\text { Denmark }(75.1) \\
\text { Netherlands }(75.1) \\
\text { Lithuania }(75.9) \\
\text { Finland }(76.3) \\
\text { Estonia }(75.7)\end{array}$ & $\begin{array}{l}\text { Denmark (80.8) } \\
\text { Estonia }(82.0)\end{array}$ & $\begin{array}{l}\text { Portugal (7.0) } \\
\text { Slovakia (6.5) } \\
\text { Sweden (6.3) } \\
\text { Lithuania (6.2) } \\
\text { Belgium (6.0) } \\
\text { Ireland }(5.8) \\
\text { Luxembourg(5.5) } \\
\text { Estonia }(5,4) \\
\text { Bulgaria (5.2), } \\
\text { Denmark (5.1) } \\
\text { Slovenia (5.1) } \\
\text { Austria (4.9) }\end{array}$ & $\begin{array}{l}\text { Netherlands } \\
\text { (4401.6) } \\
\text { Ireland (4435.6) }\end{array}$ & \\
\hline $\mathrm{Pg} / \mathrm{d} 6$ & LEBf 6 & LEBm 6 & LFPRf 6 & LFPRm 6 & UReap 6 & AMS 6 & GDPpc 6 \\
\hline $2,20-2,92$ & $84,98-86,63$ & $79,15-81,64$ & $77,55-81,8$ & $82,28-84,5$ & $4,8-1,9$ & $5193,6-6974,1$ & $78,3-90,54$ \\
\hline $\begin{array}{l}\text { Luxembourg } \\
(2,2) \\
\text { Malta }(2,8)\end{array}$ & $\begin{array}{l}\text { Italy (85.6) } \\
\text { France (85.9) } \\
\text { Spain (86.3) }\end{array}$ & $\begin{array}{l}\text { Finland (79.1) } \\
\text { Austria (79.4) } \\
\text { Belgium (79.4) } \\
\text { France (79.7) } \\
\text { Luxembourg( } 80.1) \\
\text { Netherlands (80.3) } \\
\text { Malta ( } 80.4) \\
\text { Ireland (80.5) } \\
\text { Spain (80.7) } \\
\text { Cyprus ( } 80.9) \\
\text { Sweden (80.9) } \\
\text { Italy (81.2) }\end{array}$ & Sweden $(81.0)$ & $\begin{array}{l}\text { Czech Republic } \\
\text { (83.2) } \\
\text { Netherlands (83.4) } \\
\text { Germany (83.4) } \\
\text { Malta (84.3) } \\
\text { Sweden (84.4) }\end{array}$ & $\begin{array}{l}\text { Romania }(4,2) \\
\text { Poland }(3.9) \\
\text { Netherlands }(3.8) \\
\text { Malta }(3.7) \\
\text { Hungary }(3.7) \\
\text { Germany }(3,4) \\
\text { Czech Republic } \\
(2,2)\end{array}$ & $\begin{array}{l}\text { Denmark (5487.1) } \\
\text { Luxembourg } \\
\text { (5988.8) }\end{array}$ & Luxembourg (88.2) \\
\hline
\end{tabular}

The number of groups (n) was determined by the Sturgess formula (formula 1): $\mathrm{n}=1+3,322 \cdot \lg \mathrm{N}$,

where $\mathrm{N}-$ the number of units of the population.
(1) 
Based on the grouping of the EU Member States and Ukraine has formed six groups (table. 1).

The length of the interval (i) in the groups was determined by (formula 2):

$\mathrm{i}=\frac{\mathrm{X}_{\max }-\mathrm{X}_{\min }}{\mathrm{n}}$,

where Xmax - the maximum value of the attribute in the aggregate;

Xmin - the minimum value of the attribute in the aggregate.

Presented in Table 1 analysis, allows you to determine the priorities of sustainable development. Such details can be made separately for each component of sustainable development, as well as for each goal within the framework of programs for implementing sustainable development in the region (country).

Thus, the architectonics presented in Figure 1 allows us to visualize the main conceptual provisions of the author's vision regarding the relationship, interdependence, and interaction of such elements as the economic, environmental, and social components of sustainable territorial development, the goals of sustainable development, and the phases of human capital reproduction. Also, the author's development makes it possible to present the territory as space. This approach, according to the authors, is the most appropriate in the current conditions of the development of the regional economy. The proposed architectonics is aimed at solving several problems at once, both theoretical and methodological and applied.

\section{Conclusion}

The overall strategic priority of the socio-economic development of any territory should be the creation of conditions for the comprehensive development of a person, improving his well-being, ensuring a long and healthy life, since it is by the level of human capital development that one can judge the level of socio-economic development of the country as a whole.

It is proved that the establishment of deadlines for the implementation of programs and strategies for the sustainable development of territories should take into account the specifics of the reproduction of human capital. Taking into account the fact that all the processes taking place a large time lag, when determining priorities for the implementation of programs and strategies for the development of territories for each of the phases of the reproduction of human capital, it is advisable to take into account the duration of the stages of the life cycle of the generation.

A theoretical and methodological understanding of the architectonics of human capital reproduction is proposed, which, unlike the existing ones, is represented by a triad of components, namely: elements of sustainable development (economic, environmental, social); phases of human capital reproduction (formation, use, accumulation, preservation) and sustainable development goals, which, on the one hand, allows a comprehensive approach to the formation of strategic priorities for the development of Ukrainian regions, and, on the other, to integrate with other territories in the direction of global development. The conceptual provisions of the architectonics of human capital reproduction as a strategic priority of sustainable development of territories contributed to the substantiation of the methodological principles for assessing the strategic priorities of sustainable development of territories, which in turn allowed to form the structure of the methodology for assessing the strategic priorities of sustainable development of territories.

\section{References}

1. BAKHOV I., BOICHENKO E., MARTYNOVYCH N., NYCH T., OKOLNYCHA T., VINNYCHENKO V., 2020, Conditions for Development of the Sociocultural Level of Personality in Today's Ukrainian Society, Jour of Adv Research in Dynamical \& Control Systems, 12(04): 1668-1676.

2. BELOPOLSKY N.G., 2020, Environics - fundamental science of the salvation and development of the Earth's civilization or a new concept of the development of the world, NAS of Ukraine, Institute of Industrial Economics. Kyiv.

3. BOYCHENKO E.B., 2015, Reproduction of productive forces in the context of the development of regional society: questions of theory, practice, diagnostics, Hi-Tech Press, Kyiv.

4. BRIUKHOVETSKA N.Y. IVANENKO L.V., 2020, Assessment of human capital and added value: Theory and practice, NAS of Ukraine, Institute of Industrial Economics, Kyiv.

5. ENVIRONMENT \& SOCIETY PORTAL, URL: http://www.un.org/documents/ga/res/42/ares4 2-187.htm (12.03.2021).

6. GWORGESCU-ROEGEN N., 1976, Energy and economics myths: institutional and analytical economic essays, Pergamon Press, New York.

7. HARTWICK J.M., 1977, Intergenerational Equity and the Investing of Rents from Exhaustible Resources, The American Economic Review, 67(5): 972-974.

8. MARTYNOVYCH N. BOICHENKO E., VIVCHAR O., MYSKOVA N., POPOVYCH O., KASIANENKO O., 2019, Formation of Educational Level of the Population of Ukraine in the Conditions of Formation of Information Society, International Journal of Engineering and Advanced Technology (IJEAT), 9(1): 6406-6410.

9. OFFICIAL PORTAL OF THE VERKHOVYNA RADA OF UKRAINE, http://zakon4.rada.gov.ua/ laws/show/5/2015 \#n10 (20.03.2021).

10. PAWŁOWSKI A., 2015, Zasada, czy zasady, zrównoważonego rozwoju? Wschodni rocznik humanistyczny, 11: 85-96.

11. SENGE P.M., SMITH B., SCHLEY S., LAURE J., KRUSCHWITZ N., 2008, The Necessary Revolution: How Individuals and Organizations Are Working Together to Create a Sustainable World, $2^{\text {nd }}$ ed., Crown Business, New York.

12. SKOWROŃSKI A. 2003, Wartości ekologiczne dla zrównoważonego rozwoju, Filozoficzne $i$ społeczne 
uwarunkowania zrównoważonego rozwoju, ed. Pawłowski A., Komitet Inżynierii Środowiska PAN, Lublin, 16: 25-32.

13. SOLOW R.M., 1974, Intergenerational Equity and Exhaustible Resources, Review of Economic Studies, 24-45.

14. STATE STATISTICS SERVICE OF UKRAINE, 2021, http://www.ukrstat.gov.ua/druk/publicat/kat_u /2020/zb/11/zb_yearbook_2019.pdf (07.05.2021).
15. STRELTSOVA N.L., 2014, Formation of human capital as a priority direction of innovative transformations in Ukraine, Regional collection of scientific papers on economics Prometheus, 3 (45): 72-74.

16. UN, 1987, Agenda 21, https://www.un.org/ru/documents/decl_conv/conventions/agenda21.shtml (14.03.2021)

17. WCED, 1987, Our Common Future, Cambridge University Press, New York. 